\title{
Cassia afrofistula, Kenyan Cassia ${ }^{1}$
}

Michael G. Andreu, Melissa H. Friedman, and Robert J. Northrop ${ }^{2}$

\section{Family}

Fabaceae or Leguminosae, bean family

\section{Genus}

Cassia comes from the ancient Hebrew word "quetsioth" and was first used by Dioscorides, a physician in Ancient Greece (4090 AD). Linnaeus, also known as the father of taxonomy, was the first to use Cassia to signify members of this genus.

\section{Species}

The species name afrofistula comes from a combination of two Latin words-afro, which is derived from the words afer or afrum, meaning "from Africa," and fistula, which means "hollow or pipe-like," referring here to the shape of the seedpods.

\section{Common Name}

\section{Kenyan cassia, East African cassia}

The two common names "Kenyan cassia" and "African cassia" refer to this tree's African origins.

\section{Description}

This evergreen or semi-deciduous tree is native to East Africa and can reach heights of up to 20 feet. While it may be present in Central Florida, it is primarily found in South Florida since it does not tolerate temperatures below $25^{\circ} \mathrm{F}$. The leaves of Kenyan cassia are alternate, pinnately

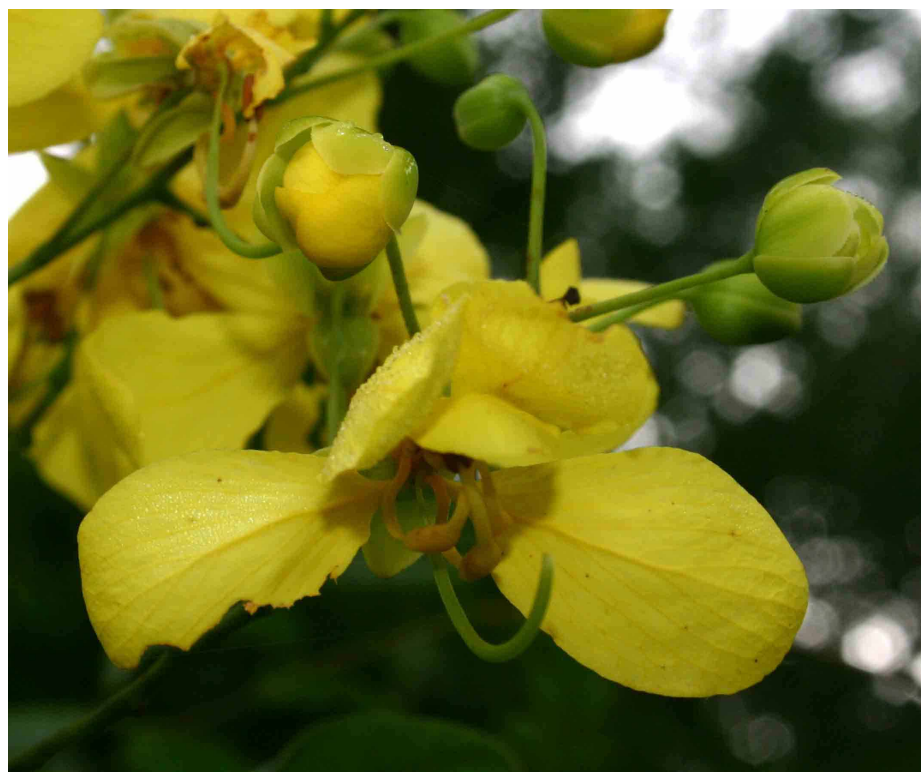

Figure 1. Detail of Cassia afrofistula (Kenyan Cassia)

Credits: Photographed by B.T. Wursten for Hyde, M.A., Wursten, B.T., Ballings, P. \& Dondeyne, S. (2012). Flora of Mozambique: Individual record no: 22305: Cassia afrofistula. http://www. mozambiqueflora.com/speciesdata/species-record.php?record_ id=22305, retrieved 26 September 2012. CC BY-NC 3.0.

compound, and reach lengths of up to 15 inches. The oppositely arranged leaflets are 1-3 inches long, oval to elliptical in shape, curved downwards, and appear in pairs of 5-10 on a leaf. The top side of each leaflet is glabrous or smooth and the underside is smooth to sparsely pubescent or hairy. The bark is brown and has smooth, vertical striations or stripes. This tree flowers just as well in light, shifting shade as it does in full sun. Kenyan cassia produces vertical spikes of showy, bright yellow flowers from late

1. This document is FOR296, one of a series of the School of Forest Resources and Conservation, Florida Cooperative Extension Service, Institute of Food and Agricultural Sciences, University of Florida. Original publication date July 2012. Visit the EDIS website at http://edis.ifas.ufl.edu.

2. Michael G. Andreu, associate professor; Melissa H. Friedman, research scientist; School of Forest Resources and Conservation; and Robert J. Northrop, Extension forester, Hillsborough County Extension; University of Florida, Gainesville, Florida 32611. 
April to September. Peak flowering from May to mid-July, with approximately 43 intense blooming days. Each petal is only $1 / 2-3 / 4$ inch in length. Some trees drop the majority of their leaves after flowering, but new leaves quickly emerge. Fruits are long, cylindrical green pods that turn black with maturity, and may hang onto the tree for many months, with a few lingering into the next flowering season. The pods are generally 8-24 inches long and are indehiscent or remain closed at maturity. Each pod produces multiple shiny, brown seeds. Cross walls or indentions in the pod separate seeds from one another, with each seed encased in dry pulp.

\section{Allergen}

Members of the Cassia genus are moderately allergenic. Oil from the pods may cause skin irritation to some individuals.

\section{Applications Horticultural}

The Kenyan cassia can be used as a showy ornamental tree or shrub, with its dark foliage and bright yellow flowers. Some people find the seed pods to be unattractive and prune the tree after it flowers to prevent pods from developing. This tree tolerates a wide range of soil types and can be used in a garden, park, patio, or streetscape setting.

\section{Additional References}

Stebbins, M. K. (1999). Flowering Trees of Florida. Sarasota, FL: Pineapple Press.

USDA Natural Resources Conservation Service (n.d.). Plants Database. Retrieved from http://plants.usda.gov/ index.html. 